\title{
Examining Succession and Replacement Planning in Work Organizations
}

\author{
Peace Ifidon Gabriel, Chris Samuel Biriowu, and Eli Legg-Jack Dagogo
}

\begin{abstract}
Succession planning and replacement planning are both strategies that are incredibly important to the lifeline of any organization. Succession planning is a deliberate and systematic effort by an organization to ensure leadership continuity in key positions, retain and develop intellectual and knowledge capital for the future, and encourage individual advancement. Replacement planning is the process of identifying short-term and long-term emergency backups to fill critical positions or to take the place of critical people. This paper examines the role of succession and replacement planning in improving organizational performance. It established the importance; types; features and objectives of succession planning in the workplace. The paper juxtaposed replacement and succession planning in the workplace, established the development plan of replacement planning and examines how succession and replacement planning helps to improve on the performance of the organization. The paper identified that succession planning and replacement planning are two different strategies; succession planning is oriented around developing people through training, mentoring, coaching, while replacement planning is focused on meeting the demands of emergencies in the organization. The paper further identified that from the perspective of the workplace succession planning helps the organization to access the risk in key position, minimizes risk through appropriate compensation, recognition and management, and assuring the readiness of successors by identifying and training high potential employees. Replacement planning assumes a stable and unchanging organizational structure, which encourages silo-d thinking about talent since in most cases; replacements come from a specific specialty area. The paper concludes that these strategies are incredibly important to the lifeline of any organization as they both assists to improve organizational performance. The paper recommends that Organizations should make use of replacement planning and succession planning; together they can mitigate the risks of any organization going out of business.
\end{abstract}

Index Terms - Replacement Planning, Succession Planning.

\section{INTRODUCTION}

In spite of the current global economic challenges facing organizations leaders of organization that are foresighted, are concerned with finding, developing and retaining the next generation of leaders when the economic condition eventually improve. When they do improve, an expected tidal wave of retirements may occur. According to Aldape (2005); and Behan (2007) it is prudent to prepare for

Published on April 05, 2020.

Peace Ifidon Gabriel, Rivers State University, Nigeria.

(e-mail: peaceogan03@yahoo.com)

Chris Samuel Biriowu, Rivers State University, Nigeria.

(e-mail: Chris.biriowu@ust.edu.ng)

Eli Legg-Jack Dagogo, Rivers State University, Nigeria.

(e-mail: dagogoleggjack2@gmail.com) emergencies, when talented people leave the organization as a result of unforeseen circumstances (Aldape, 2005; Behan, 2007). The early organization replaces key staff after they might have left the organization (Bernthal \& Wellins, 2013). This was a regular mistakes made by the early organizations in the past, replacing employees rather than to develop them (Cheng, 2016). Consequently, problems generated as a result of the replacement process, which included difficulty to find the right employee for the new vacancy in a short time period; specifically when the organizations do not find the right person from within the organizations they hire from outside which further increased the replacement costs (Drotter \& Charan, 2011).

In the past, the early organization concern on succession planning was about the exact people, not the skilled or talented worker that are needed in the organization's future (Rothwell, 2010). Then the only purpose of succession planning was to tag and identify the needed successors to replace the outgoing key staff for the specific job. Their view of Succession planning was focused on the top leaders and business owners in the large organizations (William, 2015). This affirms that, in the early corporate years, succession planning was not accorded the attention it deserves in light of the critical role that employees play in an organization's success (Pandey \& Sharma, 2014). In recent years, organizations have realized that they can discover their future key staff from within, using succession planning (Groves, 2013).

Presently, succession planning is no longer just about replacing the key executives but also entails strategic talent management, that ensures that organizations at all time should makes available a competent labour force that can help the business to continuously adapt, respond and succeed in a dynamic business environment (Nwosu, 2014). Succession planning focuses on enabling organizations develop general competencies and leadership potential at every level in the organization to foster growth and survival (William, 2015). For organizations to survive and excel in today's highly dynamic and competitive business environment, they must have a dynamic and high potential group of employee's at all organizational levels (Kamami, 2017).

Subsequently, succession planning and replacement planning are both strategies that are incredibly important to the lifeline of any organization. However, these two processes are different and have been used interchangeably over the years, often confusing, even by senior organizational leaders. As opined by Doughty, (2000); Werther, (1995) succession and replacement planning are component for organizational continuity planning; it is often 
neglected in favor of emergency planning for equipment, finances, facilities and data. This paper therefore examined succession planning and replacement planning, in establishing the importance; types; features and objectives of succession planning in the workplace. The paper further juxtaposes replacement and succession planning in the workplace, establishes the development plan of replacement planning and finally examines how succession and replacement planning helps to improve on the performance of the organization.

\section{LITERATURE REVIEW}

\section{A. Succession Planning}

Bolton and Roy (2014) defined it as a process which ensures the continued effective performance of an organization by establishing a process to develop and replace key staff over time. Gandhi and Kumar (2014) opined that succession planning as a critical strategic approach to ensuring the continued existence of essential knowledge and abilities of staff especially when key employees leave the organization. Rothwell (2010) sustained that succession planning as a deliberate and systematic effort by an organization to ensure leadership continuity in key positions, retain and develop intellectual and knowledge capital for the future, and encourage individual advancement.

The main aim of succession planning is to ensure that suitable managers are available to fill vacancies created by promotion, retirement, death or departure and to ensure that a cadre of managers is available to fill new appointments that may be created in the future (Ali, Mehmood, Ejaz \& Ashraf, 2014). Again, an important aim of succession planning is to match the organization's available talent to its needed future talent (Rothwell, 2010). Another aim is to help the organization meet the strategic and operational challenges facing it by having the right people at the right place and at the right time to do the right things (Kim, 2006). In the words of Drotter and Charan (2011), it perpetuating the enterprise by filling the pipeline with highperforming people to assure that every leadership level has an abundance of these performers to draw from, both now and in the future.

In the new perspective of succession planning, each person in an organization is a leader (Beyers, 2006). A successful succession planning show the firms commitment on leadership development programs that is beyond the normal staff development activities and interventions (Gandhi \& Kumar, 2014). Seniwoliba (2015) views succession planning as a process by which one or more successors are identified for key posts or group of similar key posts, and career move and/or development activities are planned for these successors.

\section{B. Types of Succession Planning}

According to Naveen (2006) identified three types of succession planning as designated replacement, target replacement and situational replacement:

\section{Designated Replacement}

Designated replacement succession planning can be part of a small-business owner's exit strategy or a form of continuity insurance for a larger business. Sometimes called name in the envelope succession planning, this type focuses on designating a replacement for the owner, CEO or other senior manager. A designated replacement is someone already qualified and trained, able to step in and immediately fill the role if, for example, the business owner passes away or is temporarily or permanently incapacitated.

\section{Target Date Replacement}

The second type of succession planning is similar to designated replacement planning except that plans most often designate more than one employee and don't require the employees to already be trained. Target date succession planning is used when the business knows far in advance when a key staff member will be leaving the company, usually due to retirement. This allows the business to follow a more orderly process in identifying potential replacements and following them through the training process. As the target date draws closer, the candidate field continually narrows until a single candidate becomes a designated replacement.

\section{Situational Replacement}

Situational succession plans center on uncertainty, an expected or sudden departure or a deteriorating situation. In contrast to designated and target types that create succession plans to fill a specific role, situational replacement planning isn't role-specific. Instead, it involves conducting a needs assessment and creating a pool of candidates with varying qualifications, each of whom have the potential to move into one or more roles. Skill surveys, performance reviews and tracking the results of internal and external training programs are commonly used to identify potential pool candidates. Situation succession planning saves both time and money, as hiring from within often shortens the hiring timeline and is less costly than recruiting candidates externally.

\section{Objectives of Succession Planning}

Hirsh (2000) further identified and explained the objectives of succession planning in the organization, as one of the most important HR strategic processes. The organization with the robust succession plan in place that is properly communicated and executed builds a strong competitive advantage. As employees know their importance, they tend to be reluctant to job offers from competitors. They know that they can be promoted internally; they do not have to look for the new career opportunity (Hirsh, 2000).

\section{i. $\quad$ Succession Plans Development}

The development and innovative management of the succession planning are extremely vital. This is where the human resources have to keep minds of the leadership team on all plans, and it has to define processes and procedures 
for updating on the implementation progress. It has to incorporate new talents, and it has to eliminate employees who do not participate in the system anymore. The design of the methodology is usually the first objective for $\mathrm{HR}$ Professionals in this area.

\section{ii. $\quad$ Succession Plans Execution}

The second goal of succession planning specialists is about the execution of the program. The excel spreadsheet with tons of names can be in place, but it does not say a word about the successful management of the process.

\section{iii. $\quad$ Top Talents Identification}

Human Resources have to facilitate the process, and it has to pick right people for the promotion at the right moment. These are employee's who possess and exhibit the characteristics most valuable to your organization and are ready to move into the role.

\section{iv. $\quad$ Top Talents Retention}

The successors have to be kept in the loop; they have to see a real chance to be promoted within a defined time. The organization cannot afford to select its best talents and let them leave the company because the employees realize they are valued. Many employees can find a better job with a higher salary when they mention the succession plan. Consequently, the Human Resources departments have to make sure that all personal development programs are executed, and participants are motivated and happy. It is a difficult goal but the leadership team always measures the success of the program through big numbers.

\section{v. Promotions and Success Stories}

The last general goal and objective for the succession planning is about success stories. The process needs to be based on the communication of achievement stories to the organization. Employees have to feel good vibrations when the manager tells them that they will participate in the program. It is a great honor for everyone in the program to be included. It is a role of Human Resources to send positive and vibrant messages to all audiences.

\section{Features of Succession Planning}

Deshwal (2015) identified features of succession planning as identifying succession needs, listing skills and competencies, identifying internal potential, providing training:

\section{$i$ I. Identifying Succession Needs}

Succession planning requires the ongoing consideration of areas of the company that may be at risk of losing key individuals. The first step in this process is identifying the key positions in the company that contribute most to ongoing success. While all positions are obviously important, some are more critical than others. Critical positions may be senior leadership positions, difficult-to-fill positions or new positions that may be required due to changes in the environment or the nature of the business. More than just a casual exercise, this should be a formal planning session that involves senior leaders and human resources staff in companies that have human resources departments. Clearly identifying areas at risk for succession due to attrition, retirement or new skills needs is an important step for companies large and small.

\section{ii. $\quad$ Listing Skills and Competencies}

Effective succession planning requires the specific consideration of key skills and competencies that the organization will need. Beyond simply identifying positions that may become vacant, businesses need to look at the types of skills gaps that may exist when employees leave or retire or when new business requirements emerge. For instance, the increasing prominence of social media for many organizations means that skills in this area are important.

\section{iii. Identifying Internal Potential}

One of the key benefits of succession planning is providing opportunity for internal growth and development. By matching skills needs with the availability of potential internal candidates, companies not only limit their risk, but also provide important opportunities for employees. Identifying potential internal talent can occur interactively; managers can ask employees to self-identify, indicating areas of interest they would like to develop.

\section{iv. $\quad$ Providing Training}

Once identified, those with the potential to move into future vacant positions may have training and development needs that the company can address through coaching, training and educational opportunities. Providing those opportunities is an important way to ensure candidates will be able to move into positions as they become vacant.

\section{E. Replacement Planning}

Replacement planning is the process of identifying shortterm and long-term emergency backups to fill critical positions or to take the place of critical people (Rothwell, 2011). Short-term replacement planning focuses on finding backups when a critical person is out for a short time, for example on vacation or out sick. Long-term replacement planning focuses on finding backups to fill critical positions or to fill in for critical people when they become absent for a long periods, or perhaps even forever, as a direct result of a death, disability, sudden resignation, or other sudden loss for example being held hostage (Doughty, 2000).

\section{F. Steps in Developing Replacement Planning}

There are seven steps to developing a replacement plan (Https://www.shrm.org).

\section{i. $\quad$ Identifying the Key Positions}

Because every job is important, certain roles within the organization would significantly impact the business if left open for a long period. According to SHRM, the average time to fill an open position is 42 days. Using that as your benchmark, which positions must be filled in less time? Ideally, we'd like every job to be filled quickly, but identify those that must be a priority. Those key positions are a place to start. This information is gotten from the company workforce plan.

\section{ii. Identifying the critical skills for each position}

The information needed to identify the critical skills for each position is gotten from the company staffing analysis. 
In dong this it is advisable to list the qualities of anyone admiring to holding this position must have. Because this is a replacement plan not a wish, any employee with the basic skills, should learn the other skills or knowledge required for the position.

\section{iii. $\quad$ Assessing the skills of the current employee.}

In assessing the skills of the current employees the staffing analysis should contain this information. Otherwise it can be gotten in the form of training records, performance reviews, coaching feedback, and 9-box grids. In addition, it is advisable as this can be helpful to look at the skills of freelancers and consultants who currently partner with the organization or at former employees who might be interested in returning.

\section{iv. Match the critical skills to the current skills of employees}

This step is when organizations might be tempted to think that backup employees are currently in the department for instance, the accounting manager is the obvious backup for the accounting director. However, a recent transfer might make him/her to be interested in returning to his or her former department. Keep the planning activity focused on skills, not current job titles.

\section{v. Pay attention to jobs that don't have matches}

In the course of carrying out these replacement plans the exercise will possibly surface some jobs that need immediate attention, meaning there is no replacement available. It's better to find out this information during a planning activity than when you're trying to fill an opening. This is why recruiting needs to be a part of the conversation so there are no surprises.

\section{vi. $\quad$ Develop a plan to address gaps}

This plan might include development programs, mentoring, coaching, and contingent staffing or a combination of all these programs. With replacement planning, the organization doesn't have to identify a single replacement. Use talent pools to develop transferable skills for many positions.

\section{vii. Evaluate the plan}

On a regular basis evaluate the plan to make sure the company's needs can still be met. For key positions, the individuals currently holding those roles can be tasked with helping identify their replacement and train them. This goal could become part of their performance review (Https://www.shrm.org).

\section{G. Juxtaposing Replacement and Succession Planning}

Barner (2006) distinguishes succession planning from replacement planning and argues that the aim of succession planning is to identify, retain, and prepare managers who can be dependable replacements in emergency situations. In the succession planning spectrum, replacement is at one end and succession planning is at the other end (Barner, 2006). Rothwell (2010) explains replacement planning as the process of identifying appropriate alternatives for high-level management of the organization. This is simply a prediction of the future performance of individuals. In this approach, the assumption is that the present manager is an appropriate model for future managers, which does not seem to be true in today's uncertain environment, characterized by fastchanging strategies and processes (Rothwell, 2011).

Replacement Planning might not be the one in curing all the problems as it concerns organizational continuity; rather it is based on the premise that an organization chart will remain the same over time (Doughty, 2000). It usually identifies backups for all top positions in a company. They are identified on the organization chart and it stops there. All typical replacement charts lists about three persons as backups for each of the top-level positions and indicates how far the backups are ready to take over the role of the current incumbent (Doughty, 2000). Replacement planning is focused on meeting the demands of emergencies in the organization. It is capable in avoiding long delays especially, when an important decision is to be made and the person who makes them is gone (Https://www.shrm.org). It usually focuses on searching for backups inside the organization. It thus works well in corporate cultures characterized by strong silos (divisions or specialty areas).

An understanding of the replacement chart shows that each individual's names are listed and they are ranked according to their perceived readiness to move up. RN means they are ready now; R1 means they are ready in 6 months with the right preparation/development; and R2 means they are ready in 6 months to 1 year.

According to Rothwell (2011) succession planning is different from replacement planning; it is oriented around developing people instead of merely identifying them as replacements. The goal of succession planning is to have deep bench strength all through the organization, so that whenever a position falls vacant, there are enough qualified candidates in the company, who can be considered for advancement (Rothwell, 2011). For instance, it does not focus on finding internal backups from within departments; rather, it examines the needs by level (such as the move from middle to senior manager). All talent at each level is pooled. Talent pools are thus defined as all people who are considered promotable to the next level up on the organization chart regardless of department.

When the need arises for replacement and all members of a group (like senior executives) are at or near retirement age then a special focus may be placed on accelerating the development of the talent pool. Such a group, targeted for faster development, is called an acceleration pool (Byham, 2002). An understanding of the succession planning chart simply shows that the positions are not the focus of attention; rather, levels are the focus (Rothwell, 2011). All individuals who signal interest in being considered for promotion are placed in a talent pool. 


\section{H. Succession Planning and Organizational Performance}

Succession planning is the preparation of employees for advancement, to ensure continued or, in some cases, to restore high quality performance when successors advance to key positions following exits of retirement, promotion, departure or removal of incumbents (Farley, 2005). From the organization perspective it helps to access the risk in key position, minimizes risk through appropriate compensation, recognition and management, and assuring the readiness of successors by identifying and training high potential employees (Robb, 2006). This strategy is incredibly important to the lifeline of any organization as it assists in promoting organizational performance (Sambrook, 2005).

As stated by Ali, Mehmood, Ejaz, and Ashraf, (2014) for succession planning to yield the desired outcomes, it must focus on codifying organizational knowledge and expertise amongst organizational employees, through training and development, mentoring and coaching; empowering employees to follow development paths, and stimulating learning within the organization.

\section{i. $\quad$ Training}

Training is a learning process that aims to permanently improve the ability and behavior of the employees by enabling them to acquire new skill, knowledge and attitude for more efficient performance (Deku, 2015). Training is fundamentally important in the development of employees to the organization. It could be described as the vehicle that takes organization to their destination within a stipulated time frame. According to Becker (1993), there are three types of training or knowledge, which are directly related to rate of return and human capital; they are on the job training, schooling, and specific training.

On the job training is intended to improve old skills and provide new skills while employed by a firm. These skills are either transferable or specific. On the job training is provided by a firm and utilized to increase the outputs of the firm and to increase the income of the individual. This type of training is valued through the time and effort of the trainees, the teaching provided by others, and the equipment and materials used. These are costs that are incurred from reducing current production in order to increase future production (Becker, 1993). Specific training refers to training provided by a firm that has limited transferability and only increases productivity within the contextual setting. For example, when a firm hires new employeesmany times, they are orientated to the culture, specific policies and procedures, and other processes to familiar the new employee with their organization. This type of training is specific because the knowledge acquired raises productivity in the firm providing the knowledge than in other firms. Some specific training may not be useful in a single firm or in most firms, but in a set of firms defined by a product, type of work, or geographical location (Becker, 1993). For example, French legal training would not be very beneficial in the United States, but it would be very useful in France (Becker, 1993).

School training (schooling) is completed off the job and at an institution that specializes in either one skill or multiple skills. Schools are often substitutions for on-the job training at a firm. This is evidence by the shift in training programs from the firm to the school such as legal apprenticeships to law school, and on-the-job engineering experience to engineering schools (Becker, 1993).

\section{ii. Job Rotation}

Job rotation has been defined as systematic movement of employees from one job to another at planned intervals (Dessler \& Varkkey, 2009; Malinski, 2002). It involves periodic shifting of employees from one task to another where each task requires different skills and subsequently enhances their job performance (Eitington, 1997; Leat, 2007; Campion et al., 1994). Torrington and Hall (1991) described the job rotation as movement of employees among different tasks and positions which will probably be of similar nature. Different organizations do rotate their employees from one job to another across various departments for multiple reasons depending on specific needs of an organization.

Job rotation is an important aspect of succession planning. The organization will have an opportunity to fill vacancies created as a result of promotion, transfer, retirement, death and turnover through job rotation. According to Garry Dessler (2000) and Nzuve (1999) they both show that job rotation is beneficial to the individual as well as the organization. Job rotation being a technique of job training enables management trainees from one department to the other to broaden their understanding of all parts of the business. The trainee often a recent college graduate may spend several months in each department but more commonly gets fully involved in its operations. The trainee learns the business by doing it whether it involves sales, production, finance or some other function. Nzuve (1999) stated that job rotation in an organization allows workers to diversify their activities, avoid boredom and back monotony.

There are two type of rotation vertical and horizontal. Vertical refers to promotions and demotions. However job rotation specifically refers to horizontal variety or lateral transfers. Horizontal job transfers are supposed to be instituted on a planned basis, by means of a training program whereby the employees spends two or three months in an activity and is then moved on to another job. It broadens employee' scope and gives them a range of experience. At the same time the organization. One extension of this is called job pathing, which means selecting carefully sequenced job assignments.

\section{iii. $\quad$ Coaching}

Coaching has been defined in many ways. The International Coaching Federation (ICF) describes coaching as partnering with clients in a thought provoking and creative process that inspires them to maximize their personal and professional potential (International Coach Federation, 2010). Brockbank and Ian McGill (2006) posit that the one purpose of coaching is the learning and development of an individual, a process that involves change. Brockbank (2006) Coaching is a simple yet effective form of personal development where the Client 
and Coach create an alliance that promotes and sustains the Client's personal growth and competence. This powerful relationship enables the Client to give up who they are for who they want to become.

Workplace coaching which is critical to employee performance is defined as a knowledge transfer mechanism imparted to employees as an integral aspect with the purpose of improving the workers capability and work place performance (Martin, 2005). Coaching is a powerful strategy for the 21 st Century workplace, it is a determinant of a successful firm, and it helps to clear the sense of individual values of all employees and the alignment of their goals with that of the firm. Coaching helps people to improve their performance and enhance their quality of life (Cai \& Klyushina, 2009).

\section{iv. $\quad$ Mentoring}

Mentoring refers to the process of developing formal relationships between junior and senior members of an organization (Aneeq, 2012). It entails the establishment of formal relationships between more experienced employees and less experienced employees (Aneeq, 2012). The formal relationships are created to develop careers of employees (Nyambura \& Kamara, 2017). Similarly, mentoring leads to increased job satisfaction, organization commitment and career achievement. Hayes (2015) argues that mentoring enables employees to connect, develop and grow along their own career paths.

Mentoring encourages the less experienced employees to tap into the knowledge of more experienced employees thereby leading to improvement in their performance. Mentoring is a suitable training method in that it can be channeled to fit individual employee needs (Sweeney, 2013). Galanou (2009) argued that mentoring process is one of the most important training methods for the improvement of employee productivity and aligning individual goals to corporate goals. Further, clear mentoring policies have led to the success of many organizations because employees gain more competencies leading to improved productivity (Hamid, 2011).

\section{v. Career Development}

Career development is a systematic planning method used to link employee career objectives with the corporate career needs of an organization (Kakui \& Gachunga, 2016). It entails activities undertaken by the employees themselves and the organization to achieve career objectives and job requirements. Robbins (2010) contends that career development is a key strategic consideration for all organizations regardless of size, sector, market or profile.

Organizations which aspire to be successful in today's extremely competitive markets need employees with the right competencies to assist in achieving a competitive edge in the industries. Mwanje (2010) posits that career development of employees has a fundamental impact on the efficiency, effectiveness, morale and profitability of the organization. Career development is the basis of employee confidence and competence (Robbins, 2010). Career development aids organizations in bridging the gap between current performance and expected future performance.

\section{Replacement Planning and Organizational Performance}

Replacement planning assumes a stable and unchanging organizational structure, which encourages silo-d thinking about talent since in most cases; replacements come from a specific specialty area. Replacement planning is tactical in nature but is vitally important for all companies, regardless of size. Replacement plans ensure the continuity of operations of the business as it focuses on how critical positions will be filled on short notice in order to keep the business going (Doughty, 2000). This is applying the steps to developing a replacement plan as earlier stated above.

\section{CONCLUSION}

In spite of the fact that organizations are working hard to hire, engage, and retain the best talent, it would be naïve to think that employees will never leave. From extant literature replacement planning and succession planning are very important in every organization regardless of their size. Although they are have been used interchangeably, but they are different from each order; replacement planning provide the organization with the comfort that a last-minute resignation, retirement, or employee illness will not leave the company disadvantaged and also provide the organization with a sense of the investment they will need to make should a backup be necessary. Succession planning is pro-active and future focused, it also enables managers and supervisors to assess, evaluate, and develop a talent pool of individuals who are willing and able to fill positions when needed. It is a tool to meet the necessary staffing needs of an organization/department, taking not only quantity of available candidates into consideration, but also focusing on the quality of the candidates, through addressing competencies and skill gaps.

The paper further identified steps in developing replacement plan and elements of succession planning in improving organizational performance; mentoring, training; coaching, carrier development and job rotation are tools used to increase employee skills at the same time increase the organizational performance. Therefore, it is imperative to state that succession and replacement planning are both strategies that are incredibly important to the lifeline of any organization as they assist to increase the organizational performance; through proper implementation and application of these elements and steps stated above.

\section{RECOMMENDATION}

Organizations should make use of replacement planning and succession planning; together they can mitigate the risks of any organization going out of business. Organizations should take steps to reduce the risk of vacancies, ensure that employees are talent ready to meet the needs of the organization, smoothing the transition of leaders to new positions, and deploying talent throughout the organization. These strategies are equally important and must be integrated to ensure that the organization has the talent it needs in the future. 


\section{REFERENCES}

Aldape, J. (2005). Commentary: a company's present, future leaders key to success. The Idaho Business Review, 1 .

Ali, Z., Mehmood, B., Ejaz, S., \& Ashraf, S. F. (2014). Impact of succession planning on employees performance: Evidence from commercial banks of Pakistan. European Journal of Social Sciences, 44(2), 213-220.

Aneeq, A. (2012). Impact of training in hotel industry of Lahore, Pakistan. Journal of Business Studies Quarterly, 4 (4), 23-46.

Becker, G. S. (1993). Human Capital: A Theoretical and Empirical Analysis, with Special Human Capital. Chicago: The University of Chicago Press

Bernthal, P., \& Wellins, R. (2006). Trends in leader development and succession. People and Strategy, 29(2), 31.

Bolton, J., \& Roy, W. (2004). Succession planning: Securing the future. The Journal of Nursing Administration, 34(12), 589-593.

Brockbank, A., \& McGill, I. (2012). Facilitating Reflective Learning. Coaching, Mentoring and Supervision. London: Kogan Page Publishers.

Byham, W. C. (2002). A new look at succession management. Ivey Business Journal, 66(5), 10-12.

Cai, W., \& Klyushina, U. (2009). Talent retention and development within multinational company in China.

Campion, M. A., Cheraskin, L., \& Stevens, M. J. (1994). Career-related antecedents and outcomes of job rotation. Academy of management journal, 37(6), 1518-1542.

Cheng, J. (2016). Preparing for Top Management Changes: The Relationship between Succession Planning Processes and Succession Outcomes. Strategic Management Society Annual Conference, Harvard Business School.

Deku, G. (2015). Impact of human capital development on the performance of Ghanaian road contractors (Doctoral dissertation).

Dessler, G. (2000). Human Resource Management, NewJersey.

Dessler, G., \& Varkkey, B. (2009). Training and development. Human resource management.

Doughty, K. (2000). Business continuity planning: protecting your organization's life. Auerbach Publications.

Drotter, S. J., \& Charan, R. (2001). Building leaders at every level. Ivey Business Journal, 65(5), 21-21.

Drotter, S. J., \& Charan, R. (2011). Building leaders at every level: A leadership pipeline. Ivey Business Journal, 65(5), 21-35.

Eitington, J. E. (1997). The winning manager: Leadership skills for greater innovation, quality, and employee commitment (650). Houston, Texas: Gulf Publishing Company.

Emeka, N. H. (2014). Succession Planning and Corporate Survival: A Study of Selected Nigeria Firms. The International Journal of Business \& Management, 2(9), 74.

Farley, C. (2005). HR's role in talent management and driving business results. Employment Relations Today, 32(1), 55-61.

Galanou, E. (2009). A model for evaluating the effectiveness of middle managers training courses: evidence from a major banking organization in Greece. International Journal of Training and Development, 12 (6) 221-245.

Gandhi, D., \& Kumar, P. (2014). Succession planning: Developing leaders for tomorrow to ensure organizational success. The International Journal of Business \& Management, 2(3), 1.

Groves, K.S. (2013). Integrating leadership development and succession planning best practices. Journal of Management Development, 26(3), 239-253.

Hamid, S. (2011). A study of effectiveness of training and development programmes of UPSTDC, India-an analysis. South Asian Journal of Tourism and Heritage, 4(1), 72-82.

Harrison, R. (2015). https://www. shrm. org/Pages/default. aspx. Human Resource Development: A Concise Introduction, 45.

Kakui, I. M., \& Gachunga, H. (2016). Effects of career development on employee performance in the public sector: A case of national cereals and produce board. Strategic Journal of Business \& Change Management, 3(3), 307-324.
Kamami, H. K. (2017). Effect Of Succession Planning On Performance Of Selected Livestock Products Based Corporate Firms In Kenya (Doctoral dissertation, KCA University).

Leat, M. (2007). Employee relations and Employment relationships. Exploring employee relations Burlington, MA: Elsevier Ltd, 1415.

Malinski, R. M. (2002). Job rotation in an academic library: Damned if you do and damned if you don't!.

Mwanje, S. M. (2010). Career development and staff motivation in the banking. Unpublished thesis, Kampala. Makerere University.

Nyambura, N. \&. Kamara, J. (2017). Influence of Career Development Practices on Employee Retention in Public Universities-A Case of Technical University of Kenya. Journal of Strategic Business and Change Management 4 (30) 510-522.

Nzuve, S. N. (1999). Elements of organizational Behaviour. Nairobi University Press.

Pandey, S., \& Sharma, D. (2014). Succession Planning Practices and Challenges: Study of Indian Organisations. Procedia Economics and Finance, 11(3), 152-165.

Robb, D. (2006). Succeeding with succession. HRMagazine, 51(1), 89-92.

Robbins, S. P., \& Judge, T. (2010). Essentials of Organizational Behavior, Person Education Publishing as Prentice Hall One Lake Street Upper Saddle River. New Jersey.

Rothwell, W. (2010). Effective succession planning: Ensuring leadership continuity and building talent from within. Amacom.

Rothwell, W. J. (2010). Effective Succession Planning: Ensuring Leadership Continuity and Building. Talent from Within. AMACOM.

Rothwell, W. J. (2011). Replacement planning: A starting point for succession planning and talent management. International Journal of Training and Development, 15(1), 87-99.

Rothwell, W. J., Jackson, R. D., Ressler, C. L., Jones, M. C., \& Brower, M. (2015). Career Planning and Succession Management: Developing Your Organization's Talent for Today and Tomorrow. ABC-CLIO.

Seniwoliba, J. A. (2015). Succession planning: Preparing the next generation workforce for the University for Development Studies.

Torrington, D., \& Hall, L. (1991). Personal management: a new approach. Prentice Hall.

Werther, W. B. (1995). Continuity Planning as a Dimension of Corporate Governance. Human Resource Planning, 18(4).

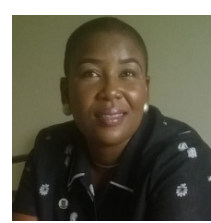

Peace Ifidon Gabriel is a Doctoral Candidate in the Department of Management, Faculty of Management Sciences, Rivers State University, Port Harcourt, Rivers State, Nigeria.

Chris Samuel Biriowu is a Lecturer in the Department of Management, Faculty of Management Sciences, Rivers State University, Port Harcourt, Rivers State, Nigeria.

Eli Legg-Jack Dagogo is a Doctoral Candidate in the Department of Management, Faculty of Management Sciences, Rivers State University, Port Harcourt, Rivers State, Nigeria. 